\title{
Complexo Imunogênico para o desenvolvimento de vacinas orais
}

\section{M.C.A. Fantini}

\author{
Departamento de Física Aplicada, Instituto de Física, \\ Universidade de São Paulo, São Paulo, Brasil.
}

\begin{abstract}
Sílica mesoporosa ordenada (SMO) mostrou-se um adjuvante/veículo efetivo para vacinação por via oral. Diferentes antígenos [2-4] foram encapsulados na SMO do tipo SBA-15 [4] e a produção de anticorpos foi monitorada para a proteína recombinante Intl $\beta(16.5 \mathrm{kDa}), \sim 20$ proteínas de veneno de cobra Micrurus ibiboboca (84 to $7 \mathrm{kDa})$, Bovine Serum Albumin, BSA, (66 kDa) e partículas do tipo vírus da Hepatite B, proteína HBsAg (> $3000 \mathrm{kDa}$ ). A capacidade de encapsular os antígenos foi determinada por isotermas de adsorção de nitrogênio (nitrogen adsorption isotherm, $N A I$ ) e espalhamento de raios $\mathrm{X}$ a baixo ângulo (small angle X-ray scattering, SAXS). A simulação de dados de SAXS in-situ da liberação BSA em PBS e fluidos gastro-intestinais revelaram uma evolução lenta do conteúdo da BSA para fora da SBA-15, independentemente do meio. A cobertura do complexo imunogênico com o polímero Eudragit@ e a estabilidade da SBA-15 nos meios líquidos (solução de água e PBS) e fluidos corporais mimetizados foram avaliadas. Os experimentos mostraram a capacidade da SBA-15 de incorporar várias moléculas em sua estrutura, bem como a influência do Eudragit ${ }^{\circledR}$ (insolúvel em meio ácido e solúvel em meio básico) na dinâmica de liberação. Estudos biológicos mostraram que a SBA-15 é um excelente adjuvante/veículo protetor para vacinas, quando comparada com o composto tradicional, $\mathrm{Al}(\mathrm{OH})_{3}$, e não é tóxica para camundongos, ratos, cachorros e mesmo células, como macrófagos e células dendríticas. O silício presente nas paredes amorfas é liberado dos órgãos de camundongos e nas fezes. Os estudos também mostraram que a resposta imunológica é melhorada através do aumento na resposta inflamatória e no recrutamento de células competentes do sistema imune para o local da injeção e por administração via oral, aumentando a fagocitose pelas células apresentadoras de antígenos.
\end{abstract}

[1] Mercuri, L.P. et al., Small, 2, 254-256 (2006).

[2] Carvalho, L.V., et al., Vaccine, 28, $7829-7836$ (2010).

[3] Mariano-Neto, F., et al., J. Phys. D: Appl. Phys., 47, 425402-425412 (2014).

[4] Zhao, D. et al, Science, 279, 548-552 (1998).

Agradecimentos: FAPESP; CNPq. 